\title{
ABSTRACT AND KEY WORDS
}

This article seeks to explain the meaning and significance of the language of conscience in private law. In doing so, it draws on the etymology and ordinary meaning of conscience and recent work relating to the distinction between obligations and liabilities. It argues that the language of conscience plays a significant, albeit highly general, explanatory role in the context of equitable obligations, such as the obligation of confidence, trust obligations and the obligations of knowing recipients. The language of conscience has less explanatory force in the context of primary liabilities, such as the liability to make restitution or rescind a contract in response to a defective transfer, and various forms of estoppel. The article argues further that the indiscriminate use of the language of conscience in the context of both equitable obligations and primary liabilities can generate confusion and uncertainty. Nevertheless, if due attention is paid to its explanatory limits and the context in which it is used, its continued presence in private law is valuable.

Key Words: conscience; unconscionability; equity; trusts; restitution; contract; estoppel

WORD COUNT

Text: $\quad 9,787$

Footnotes: $\quad 3,184$ 


\section{INTRODUCTION}

The invocation of the language of conscience in private law is controversial. On the one hand, the courts frequently use the language of conscience and unconscionability ${ }^{1}$ in a wide range of common law and equitable doctrines. ${ }^{2}$ On the other hand, critics argue that such language is vague and likely to give rise to legal uncertainty and the unacceptable conflation of law and morality. ${ }^{3}$ This article seeks to explain the meaning and significance of the language of conscience in English private law doctrine. It begins by considering the etymology and ordinary meaning of conscience and unconscionability, and how these ideas developed in equity. It then draws on recent work ${ }^{4}$ relating to the difference between obligations and primary liabilities ${ }^{5}$ as a framework for considering the different doctrines in which the language of conscience is used.

First, the article considers how the language of conscience is used in the context of primary equitable obligations, such as the obligation of confidence, the trust obligation and the obligation of a knowing recipient. This language can be interpreted consistently with its ordinary meaning to refer to the way in which moral duties arise, and to highlight moral fault in the breach of such duties. It helps us to understand the significance of factual knowledge as a doctrinal prerequisite to their recognition and enforcement. In so doing, it reveals that equity requires that defendants can engage in moral reasoning before it will compel them to act in a particular way, and it highlights the moral basis of equitable obligations.

The article goes on to discuss how the language of conscience is used in the context of primary common law and equitable liabilities, such as those which arise in the context of restitution and rescission for defective transfers, and in the context of estoppel. Here, again, it bears its ordinary meaning. Its presence indicates the courts' reluctance to impose a liability which restricts the defendant's exercise of her legal rights unless there are good moral reasons for doing so, e.g., because she breached a moral duty in the acquisition of those rights or it would now be a breach of moral duty for her to exercise them fully. However, as primary liabilities never depend on the existence and breach of a pre-existing legal duty, and rarely, if ever, depend on the existence and breach of a pre-existing moral duty, the explanatory force of the language of conscience in this context is much weaker.

The article concludes that if the explanatory limits of the language of conscience and the different contexts in which it is used are properly understood, it need not generate as

\footnotetext{
${ }^{1}$ Save where otherwise indicated, these terms will be collectively referred to as 'the language of conscience'.

2 E.g., trusts, breach of confidence, knowing receipt, relief for defective transfers, estoppel, relief against penalties, forfeiture, rectification for mistake. It is not possible to discuss all these doctrines within the scope of this article: the last three examples will be considered elsewhere. For similar reasons, this article does not engage in a comparison of the concepts of conscience, good faith and fairness.

${ }^{3}$ P. Birks, 'Equity in the Modern Law: An Exercise in Taxonomy' (1996) 26 UWAL Rev 1, 16-17; P. Birks, 'Equity, Conscience and Unjust Enrichment' (1999) 23 MULR 1, 14-15; C. Rickett, Unconscionability and Commercial Law' (2005) 24 UQLJ 73, 74; R. Havelock, 'Conscience and Unconscionability in Modern Equity' (2015) 9 Jo Eq 1, 23-28.

${ }^{4}$ E.g., S. Smith, 'A Duty to Make Restitution' (2013) 26 Canadian Law and Jurisprudence 157; and P. Jaffey, Private Law and Property Claims (Hart 2007), e.g., 23-24.

${ }^{5}$ A distinction which is not always addressed in other accounts of conscience: e.g., D. Klinck, 'The Nebulous Equitable Duty of Conscience' (2005) 31 QLJ 206; G. Virgo 'Whose Conscience? Unconscionability in the Common Law of Obligations' in A. Robertson \& M. Tilbury (eds), Divergences in Private Law (Bloomsbury 2016).
} 
much confusion or legal uncertainty as might otherwise be supposed, and there are good reasons for its continued presence in private law doctrine.

\section{CONSCIENCE - ETYMOLOGY AND ORDINARY MEANING}

The roots of the word 'conscience' are to be found in the Greek word suneidesis and the Latin word conscientia, which were understood as 'the state (or act) of sharing knowledge or else simply knowledge, awareness, apprehension'. ${ }^{6}$ Our contemporary understanding of conscience derives from these roots and has been heavily influenced by Christian theology along the way, ${ }^{7}$ particularly by the work of Aquinas. The idea of conscience refers to both factual and moral consciousness. ${ }^{8}$ In turn, the idea of moral consciousness presupposes a human faculty to distinguish right from wrong. Aquinas referred to this faculty as 'synderesis', ${ }^{9}$ which in his view described the inbuilt human capacity for understanding 'the external, objective moral law', i.e., the law of God. ${ }^{10}$ The Thomist idea of conscience involves an act of applied knowledge, an internal process by which synderesis combines with factual knowledge of a relevant situation, ${ }^{11}$ to enable individuals to reach conclusions as to the moral quality of their actions.

The contemporary definition of 'conscience' includes the following descriptions: '(An) inward knowledge or consciousness', 'a moral sense of right or wrong' and 'the faculty or principle that leads to the approval of right thought or action and condemnation of wrong', 'sense of guilt with regard to a thought or action'. ${ }^{12}$ It also refers to 'practice of or conformity with what is considered right ${ }^{13}$. Consistently with the Thomist idea of conscience, therefore, our contemporary understanding of conscience refers to both the process of reasoning towards moral judgments and the standards by which we make them. It helps us to judge the moral quality of our past actions and to decide what we ought or ought not to do now or in the future. ${ }^{14}$ 'Unconscionable' means 'showing no regard for conscience; not in accordance with what is right or reasonable ... unreasonably excessive; egregious, blatant ... having no conscience; not controlled by conscience; unscrupulous. ${ }^{15}$ This definition encompasses both a failure to act in accordance with what is morally right, and deliberate and flagrantly immoral behaviour. The ideas of unconscionability and unconscientiousness overlap to the extent that both terms may describe a failure to do what is morally right. However, in its more popular sense the term 'unconscientious' tends to denote a lack of effort or scruple, ${ }^{16}$ whilst it would be more usual to reserve the term, 'unconscionable' to describe deliberate or particularly contumelious moral transgressions.

\footnotetext{
${ }^{6}$ C.S. Lewis, Studies in Words ( $2^{\text {nd }}$ ed) (CUP 1967) 181; Shorter Oxford English Dictionary ( $5^{\text {th }}$ ed) (OUP 2002), vol 1, 490.

${ }^{7}$ D. Klinck, Conscience, Equity and the Court of Chancery in Early Modern England (Ashgate 2010).

${ }^{8}$ St. Thomas Aquinas, Summa Theologica (Fathers of the English Dominican Province tr, Benziger Bros. edn 1947) Pt I (1), 79, art 13; Lewis (n 6) 190.

${ }^{9}$ Aquinas (n 8) Pt I (I), 79, art. 12.

${ }^{10}$ Klinck (n 7) 32.

${ }^{11}$ ibid 34.

12 Shorter Oxford English Dictionary (n 6) vol 1, 490.

${ }^{13} \mathrm{ibid}$

${ }^{14}$ Lewis (n 6) 194; I. Samet, 'What Conscience Can Do For Equity' (2012) 3 Jurisprudence 13, 20

${ }^{15}$ Shorter Oxford English Dictionary (n 6) vol 2, 3421.

${ }^{16}$ ibid.
} 
Any discussion of the idea of conscience or its meaning inevitably prompts questions of moral philosophy, which go well beyond the scope of this article. The idea of conscience cannot help us to choose between a virtue-based, ${ }^{17}$ deontological ${ }^{18}$ or consequentialist ${ }^{19}$ conceptualization of morality, and it can accommodate both subjectivist ${ }^{20}$ and objectivist ${ }^{21}$ approaches to the question of how we decide what is right or wrong. For example, A's religious or political beliefs may lead her to believe that she may rightly kill her neighbour. Having killed him, she may then say that she behaved morally because she acted in accordance with what her conscience tells her is right, and therefore her conscience is 'clear'. If we take a more objectivist approach to morality, we would say that in fact her conscience was unsound, and that she failed to act 'according to good conscience'. ${ }^{22}$

Nevertheless, the language of conscience is helpful in describing the incidence of moral duties. There is support for the view that certain types of morally valuable behaviour, such as keeping our promises ${ }^{23}$ or returning something which does not belong to us, may be regarded as moral duties in the sense that they provide a reason to act with which we are in some sense bound to conform. ${ }^{24}$ It seems harsh to treat an individual as bound by a moral duty unless she has sufficient knowledge of the facts which require her to act in a specific way. The idea of conscience as applied knowledge helps us to understand this. If an individual's conscience is affected by knowledge, i.e., if she has knowledge of the relevant facts, she can reason morally as to what she ought to do, and it is not unreasonable to treat her as bound by a moral duty to do it. Conversely, if, due to the absence of factual knowledge, she is not capable of reasoning morally as to what she ought to do, she should not be treated as being subject to a binding moral duty. Therefore, it does not seem inappropriate to say that a moral duty may be experienced as a 'demand of conscience'. ${ }^{25}$ Beyond this, the language of conscience tells us little about moral duties: we do not expect it to help us identify the moral principles upon which a particular moral duty is grounded, nor to give detailed content to the duty or indicate how much knowledge is required to trigger it.

Similarly, the term 'unconscionable' is apt to describe breaches of moral duty. On the basis that an individual has the requisite factual knowledge for the duty to arise in the first place, she may breach it in one of two ways. Her conscience may misfire because her moral understanding is defective, and it does not alert her to the correct moral course of action. Therefore, her behaviour may be described as unconscionable in the very broadest sense of the word. She has failed to act in accordance with what is morally right. Alternatively, her conscience may work perfectly well, in the sense that she understands morally what the correct course of action is, but she simply ignores or overrides the signals her conscience is sending her. ${ }^{26}$ In this instance, her behaviour is unconscionable in a narrower sense, as she has consciously and deliberately flouted moral standards. Although the term,

\footnotetext{
${ }^{17}$ R. Hursthouse, On Virtue Ethics (OUP 1999) 1.

18 ibid.

19 ibid.

${ }^{20}$ L. Pojman, P. Tramel, Moral Philosophy: A Reader (4 ${ }^{\text {th }}$ ed) (Hackett Publishing 2009) 19.

${ }^{21}$ R. Dworkin, 'Objectivity and Truth: You'd Better Believe It' (1996) 25 Philosophy and Public Affairs 87, 92; for more on the different approaches, see P. Cane, Responsibility in Law and Morality (Hart 2002) 13.

22 D. Klinck, 'The Unexamined “Conscience” of Contemporary Equity' (2001) 46 McGill LJ 571, 600.

23 J. Raz, 'Promises and Obligations' in P. Hacker and J. Raz (eds), Law, Morality and Society (OUP 1977).

${ }^{24}$ L. Green, 'Law and Obligations' in J. Gardner and S. Shapira (eds), The Oxford Handbook of Jurisprudence and Philosophy of Law (2 ${ }^{\text {nd }}$ edn, OUP 2004) 516.

25 J. Finnis, Natural Law and Natural Law Rights ( $2^{\text {nd }}$ edn, OUP 2011) 297.

${ }^{26}$ Samet (n 14) 33-34.
} 
'unconscionable' is wide enough to include both types of conduct, we tend to associate the adjective more closely with conscious and deliberate moral transgressions.

\section{THE DEVELOPMENT OF THE IDEA OF CONSCIENCE IN PRIVATE LAW}

The early development of the idea of conscience in equity seems to have been influenced by the Thomist understanding of conscience, ${ }^{27}$ i.e., as a process of applied knowledge. Klinck suggests that the idea of conscience in equity presupposed an objective, external standard of morality, which was initially informed by divine law, and which subsequently infused the substantive doctrines of equity as they developed through precedent. ${ }^{28}$ Although ecclesiastical ideas of conscience were also influential in the development of the common law, ${ }^{29}$ a defining feature of the medieval Chancery jurisdiction was that it operated as a court of conscience, unhampered by the very limited common law rules of pleading and proof, and with access to the defendant's knowledge of the facts in a fashion denied to the common law judges, ${ }^{30}$ e.g., through the writ of subpoena. This may explain why, although ideas of conscience do still appear in the common law, ${ }^{31}$ in practice, the language of conscience tends not to feature in the courts' treatment of common law duties, even where they are framed in moral terms. ${ }^{32}$

Today, when the courts use the language of conscience in equity and (occasionally) at common law, they also appear to treat the idea of conscience as based on objective, rather than personal, standards, ${ }^{33}$ derived through the process of legal reasoning from 'settled rules and decided cases'. ${ }^{34}$ They have rejected any suggestion that the idea of unconscionability provides a basis for the court to create a general power to relieve a party from her legal obligations. $^{35}$ Instead, what good conscience requires, and/or what is regarded as unconscionable, is informed by the principles and rationale of each doctrine. ${ }^{36}$ As Samet explains, ${ }^{37}$ the fact that the idea of conscience admits of the possibility of objective moral values is essential to its legal significance. Otherwise, conscience would merely be a synonym

\footnotetext{
${ }^{27}$ Klinck, 'Conscience, Equity and the Court of Chancery' (n 7) 31, 32, 34; M. Drakopoulou, 'Equity, Conscience and the Art of Judgment as lus Aequi et Boni' (2000-2001) 5 Law Text Culture 345, 351.

${ }^{28}$ ibid; H. Coing, 'English Equity and the Denunciato Evangelica of the Canon Law' (1955) 71 LQR 223, 230-231;

T. Plucknett and J. Barton (eds), St German's Doctor and Student (Selden Society 1974) 89, 111; Klinck, 'Lord Nottingham and the Conscience of Equity' (2006) 67 Journal of the History of Ideas 123; Klinck, 'Conscience, Equity and the Court of Chancery' (n 7) 53-56, 229-230.

${ }^{29}$ L. Knafla, 'Conscience in the English Common Law Tradition' (1976) UTL 1, 3, 4; N. Doe, Fundamental Authority in Late Medieval English Law (Cambridge University Press 1990) 137, 130-140, 144, 147-148.

${ }^{30}$ M.Macnair, 'Equity and Conscience' (2007) 27 OJLS 659.

${ }^{31}$ E.g., the doctrine 'lawful act duress'.

${ }^{32}$ E.g., the duty of care: D. Ibbetson, A Historical Introduction to the Law of Obligations (OUP 1999) 166-167, $170,191,196-197$.

${ }^{33}$ Uglow v Uglow [2004] EWCA Civ 987, [30]-[32] (Mummery LJ); Pitt v Holt [2013] UKSC 26; [2013] 2 AC 108; Tanwar Enterprises Pty Ltd v Cauchi (2003) 217 CLR 315 (HCA) [20]; Kakavas v Crown Melbourne Ltd [2013] HCA 25, [15], [16]. See also Jones v Morgan [2001] EWCA Civ 995; Klinck, 'The Unexamined “Conscience"”' (n 22) 604 .

${ }^{34}$ Commonwealth v Verwayen (1990) 170 CLR 394, 441 (Deane J).

${ }^{35}$ Union Eagle $v$ Golden Achievement [1997] AC 514, 519 (Lord Hoffmann).

${ }^{36}$ Tanwar (n 33) [84], [88] (Kirby J); ACCC v CG Berbatis Holdings Pty Ltd (2003) 214 CLR 51 (HC), 72 (Gummow and Hayne JJ); J. Wilson, 'The Institutional and Doctrinal Roles of "Conscience" in the Law of Contract' (2005) 11 Auckland UL Rev 1, 3, 7; Samet (n 14) 16; Virgo (n xx) 305; Klinck, 'The Unexamined “Conscience"' (n 22) 606-607.

${ }^{37}$ Samet (n 14) 20, 25.
} 
for sincerity ${ }^{38}$ or good faith (the hallmark of which is sincerity of intention ${ }^{39}$ ), and the legality of behaviour for the purposes of private law is rarely, if ever, ${ }^{40}$ measured by reference to sincerity alone. The dominant idea of conscience in private law appears to be an objective one.

The idea of conscience in private law is not a term of art. The courts use the language of conscience and unconscionability in accordance with its ordinary meaning to describe the incidence of moral duties, and the defendant's moral fault in breaching such duties. The doctrines in which the language of conscience is used tend to involve either the enforcement of equitable obligations or the restriction of legal rights through the imposition of primary liabilities. This distinction is explained in section IV. Sections V and VI go on to explain what the language of conscience means and how it is used in each context.

\section{THE DISTINCTION BETWEEN OBLIGATIONS AND PRIMARY LIABILITIES}

In private law, there is a difference between obligations and liabilities. A duty or obligation involves 'a genuine prescription or requirement for action (or inaction)' ${ }^{41}$ If the defendant is under a primary legal duty which corresponds to a right held by the claimant, ${ }^{42}$ and she breaches that duty, she commits a civil wrong ${ }^{43}$ and must compensate for any loss and/or account for her gains. Even in cases where the breach of duty has caused no harm, damages are usually available in response to the wrong 'precisely in order to make clear that a wrong has occurred. ${ }^{44}$ It follows that, as Smith argues, 'duty-imposing rules tell citizens how to act (and how others should act towards them)'. ${ }^{45}$ In his view, the actions required by legal duties tend to give effect to moral duties, and so any court orders made in such cases tend to replicate the pre-existing duty. ${ }^{46}$

By contrast, a liability is a susceptibility to the alteration of one's legal position through the exercise of a power by another. ${ }^{47}$ Some legal liabilities arise secondarily, i.e., because a legal duty has been breached by the defendant. However, this is not always the case. It is also possible for liabilities to be primary or free-standing, ${ }^{48}$ in the sense that they do not depend on the existence or breach of a legal duty. Smith argues that by contrast with dutyimposing rules, "liability-imposing rules (or more strictly "liability to orders imposing rules") tell citizens what the state may do to them (and what they may cause the state to do to others). ${ }^{49}$ In his view, any orders made by the courts in such cases do not replicate existing duties and may be regarded as 'creative'. ${ }^{50}$ He also argues that when we try to explain creative orders which impose primary liabilities, they must be justified by reasons other than

\footnotetext{
38 J. Ratzinger, 'Conscience and Truth' (10 ${ }^{\text {th }}$ Workshop for Bishops, Dallas, Texas, February 1991) 1.

${ }^{39}$ Shorter Oxford English Dictionary (n 9) 916.

${ }^{40}$ Cf. Twinsectra Ltd v Yardley [2002] UKHL 12; [2002] 2 AC 164, [27]-[36] (Lord Hutton).

41 Jaffey Private Law and Property Claims (Hart Publishing 2007) [xx]

${ }^{42}$ W. Hohfeld, 'Fundamental Legal Conceptions' (1913) 23 Yale LJ 29; M. Kramer, 'Rights Without Trimmings $[\mathrm{xx}] 9$.

${ }^{43}$ P. Birks, 'Rights, Wrongs and Remedies' (2000) 20 OJLS 1, 31.

${ }^{44}$ Smith (n xx) 169-70.

${ }^{45}$ Smith (nxx) 162.

${ }^{46}$ Smith ( $\mathrm{nx}$ ) 163-64.

${ }^{47}$ Hohfeld (n xx) 44-54; Kramer (n xx) 20.

${ }^{48}$ Smith ( $\left.\mathrm{xx}\right)$ 162; also Jaffey ( $\left.\mathrm{xx}\right) 23$.

${ }^{49}$ Smith ( $\left.\mathrm{nxx}\right) 162$.

${ }^{50}$ Smith (n xx) 163.
} 
the idea that the law is giving effect to the defendant's moral duties. ${ }^{51}$ As will be seen below, however, the courts tend to use the language of conscience in the context of both primary equitable obligations and primary common law and equitable liabilities.

\section{CONSCIENCE, KNOWLEDGE AND THE INCIDENCE OF PRIMARY EQUITABLE OBLIGATIONS}

This section discusses how the courts use the language of conscience in relation to three examples of primary equitable obligations: the obligation of confidence, the trust obligation and the obligation of a knowing recipient.

\section{A. Meaning}

The exclusive equitable jurisdiction to restrain a breach of confidence has been said to lie in 'the notion of an obligation of conscience arising from the circumstances in or through which the information was communicated or obtained. ${ }^{, 52}$ Originally, this obligation depended on a relationship of confidence between the parties. ${ }^{53}$ Now, a primary equitable duty of confidence arises once the defendant knows or has notice that the information is confidential, ${ }^{54}$ in the sense that it is information to which a reasonable expectation of privacy attaches. ${ }^{55}$ If she then uses it inconsistently with its confidential nature, ${ }^{56}$ she will have breached her duty of confidence. Lord Neuberger recently described the action as 'based ultimately on conscience'. ${ }^{57}$ The defendant's conscience is affected 'if she agreed, or knows that the information is confidential. ${ }^{58}$ Thus, from the moment the defendant 'is told, or otherwise appreciates that it is in fact confidential ... it can be said that her conscience is affected in such a way which should be recognized by equity. ${ }^{, 59}$

Trust obligations are also said to be based on conscience. According to Lord BrowneWilkinson, '[s]ince the equitable jurisdiction to enforce trusts depends upon the conscience of the holder of the legal interest being affected, he cannot be a trustee of the property if and so long as he is ignorant of the facts alleged to affect his conscience, i.e., until he is aware that he is intended to hold the property for the benefit of others in the case of an express or implied trust, or, in the case of a constructive trust, of the factors which are alleged to affect his conscience. ${ }^{60}$ Express trustees are 'conscience-bound' to hold 'legal title to the property for the benefit of the beneficiaries in accordance with [the] trust instrument. ${ }^{.61}$ It has been held that the recipient of money paid under a contract pursuant to innocent misrepresentation would not be treated as a non-express trustee of the money 'so long as he

\footnotetext{
51 Ibid 165.

52 Moorgate Tobacco Co Ltd v Philip Morris Ltd (No. 2) (1984) 156 CLR 414, 438 (Deane J).

${ }^{53}$ Morrison v Moat (1851) 9 Hare 241, 256, 261; 68 ER 492, 498 (Turner VC); Saltman Engineering Co Ltd v Campbell Engineering Co Ltd (1948) 65 RPC 203; [1963] 3 All ER 413, 414 (Lord Greene MR).

${ }^{54}$ A $v$ v Guardian Newspapers (No. 2) [1990] AC 109 (HL), 281 (Lord Goff); Campbell v MGN Ltd [2004] 2 AC 457 (HL), [14] (Lord Nicholls), [48] (Lord Hoffmann).

55 J. McGhee QC (ed), Snell's Equity (33 ${ }^{\text {rd }}$ edn) (Sweet \& Maxwell 2015) [9-005].

${ }^{56}$ Vestergaard Frandsen A/S v Bestnet Europet Ltd [2013] UKSC 31; [2013] 1 WLR 1556 [23] (Lord Neuberger PSC).

57 ibid [22].

58 ibid.

59 ibid [25].

${ }^{60}$ Westdeutsche Landesbank Girozentrale v Islington LBC [1996] AC 669 (HL), 705.

${ }^{61}$ Re Reynolds: Official Assignee v Wilson [2008] NZCA 122; (2007-2008) 10 ITEL 1064, [118] (Robertson J).
} 
was ignorant of the facts which brought his authority to an end, for those are the facts which are alleged to affect his conscience and subject him to an obligation to return the money to [the claimant]. ${ }^{62}$ Similarly, the courts' jurisdiction to treat a fiduciary as holding a bribe on constructive trust for his or her principal has been described as a case 'where equity, acting on the defendant's conscience, enforces a personal obligation in relation to property. ${ }^{63}$

It is said that in cases of knowing receipt, 'equity is concerned with [the recipient's] knowledge of equitable interests because it is concerned with fastening upon the conscience of the person with that knowledge. ${ }^{64}$ Historically, the fundamental question was said to be 'whether the conscience of the recipient is bound in such a way as to justify equity in imposing a trust on him' ${ }^{65}$ The characterization of knowing recipients as constructive trustees still has its champions ${ }^{66}$ but has fallen out of favour with the courts. ${ }^{67}$ However, it is clear that she is regarded as being subject to an equitable obligation to restore the assets to the claimant, ${ }^{68}$ or not to part with the property or use it for her own benefit. ${ }^{69}$ Thus, the key question is whether the recipient's 'conscience ... became sufficiently affected for it to be right to treat him as bound by obligations in equity giving rise to an in personam claim against him as recipient to account for the money which came into his hands. ${ }^{70}$ This will be the case if she has sufficient knowledge of the material facts, i.e. that the property was traceable to a breach of trust. $^{71}$

In the absence of any indication that the term 'conscience' is being given a specific legal definition in these doctrines, it may be interpreted consistently with its ordinary meaning. In all three cases, the language of conscience suggests that if the defendant has knowledge of the relevant facts, this activates her capacity for moral reasoning. It is only through the process of moral reasoning - i.e., through the operation of her conscience - that she can work out what she ought, morally, to do in the circumstances. At this point, but not before, it becomes reasonable to treat her as being subject to an 'obligation of conscience', i.e., a positive moral duty, which equity underwrites as an enforceable equitable obligation. Thus, the language of conscience tells us that the courts regard the relevant equitable obligation as a moral duty, ${ }^{72}$ which will only arise if the defendant has the requisite factual knowledge.

\section{B. Explanatory Role}

The language of conscience plays a distinctive explanatory role in relation to primary equitable obligations. In the three examples referred to above, knowledge is an ingredient

\footnotetext{
${ }^{62}$ Bristol \& West Building Society v Mothew [1998] Ch 1 (CA), 23 (Millett LJ).

63 P. Millett, 'Bribes and Secret Commissions Again' (2012) 71 CLJ 583, 599-600.

${ }^{64}$ Selangor United Rubber Estates Ltd v Cradock and Others (no. 3) [1968] 1 WLR 1555 (Ch) 1583, 1615

(Ungoed-Thomas J).

${ }^{65}$ Re Montagu's Settlement Trusts [1987] Ch 264, 277 (Megarry VC).

${ }^{66}$ C. Mitchell \& S. Watterson, 'Remedies for Knowing Receipt' in C. Mitchell (ed), Constructive and Resulting

Trusts (Hart 2010).

${ }^{67}$ Williams v Central Bank of Nigeria [2014] UKSC 10, [2014] AC 1189, 1206 [26], [31] (Lord Sumption JSC), [90]

(Lord Neuberger JSC).

${ }^{68}$ Williams (n 67) [31].

${ }^{69}$ Independent Trustee Services Ltd v GP Noble Trustees Ltd [2012] EWCA Civ 195 [82] (Lloyd LJ).

${ }^{70}$ Relfo v Varsani [2014] EWCA Civ 360 [78].

${ }^{71}$ El Ajou v Dollar Land Holdings [2994] 1 BCLC 464 (CA), 478 (Hoffmann LJ).

72 E.g., Sekhon v Alissa [1989] 2 FLR 94 (Ch), 99 (Hoffmann J).
} 
of the cause of action in the sense that it is a prerequisite to the recognition and enforcement of the relevant obligation. The courts do not need to use the language of conscience to tell us this, and thus it might appear to be superfluous at doctrinal level. However, in fact the language of conscience tells us something about why factual knowledge is a doctrinal requirement, i.e., because, without it, the individual is not able to reason morally as to what she ought to do, and it is only when she can do this that equity will treat her as being subject to an enforceable equitable obligation. When the language of conscience is used in this way, equity is looking forwards: it asks if the defendant is capable of complying with a particular moral standard. If so, it will treat her as bound by a contiguous, primary equitable duty, and require her to take positive action to comply with it.

That said, the language of conscience has three obvious limitations, which means that its explanatory role in relation to equitable obligations operates at a high level of generality. First, and most obviously, it cannot help us to identify the principles or values which underpin an equitable obligation. This requires direct discussion about those principles or values themselves. For example, although the language of conscience may tell us there are good moral reasons to enforce trust obligations, it does not tell us what they are. This will depend on the type of trust and the principles on which it is thought to be based. And merely to say that a knowing recipient will be subject to an equitable obligation if her conscience is sufficiently affected suggests that there are good moral reasons for imposing the obligation, but it does not tell us what those reasons are.

Second, of itself the language of conscience cannot give detailed content to the relevant obligation. For example, if $B$ obtains information in confidence, she must not use it inconsistently with its confidential nature, ${ }^{73}$ nor may she use it as a spring-board for activities which might cause detriment to $A$. However, the language of conscience itself cannot help us to work out how 'a conscientious recipient' of technical information which is partly public and partly private is 'to comply with the requirements that equity lays on him', ${ }^{74}$ just as it does not identify the type of duty or duties to which a trustee is subject. An express trustee may have custodial, administrative and fiduciary duties, ${ }^{75}$ whereas the effect of the imposition of a constructive trust over a bribe received by a fiduciary seems to be primarily to obligate the fiduciary to deliver up the bribe and any profits made from it to her principal in specie. ${ }^{76}$ Both may be described as obligations of conscience.

Similarly, although the language of conscience tends to suggest that a knowing recipient ought not to keep the property for her own benefit, further work is required to clarify the precise nature of the equitable obligation. On one analysis, the recipient is subject to a primary duty not to interfere with another's equitable property rights, the breach of which is akin to conversion and triggers a (secondary) obligation to account. ${ }^{77}$ On another analysis, the recipient's knowledge triggers a primary custodial duty, which resembles an express trustee's duty to account. ${ }^{78}$ She is therefore properly described as a constructive trustee, her continued retention of the property is unauthorised, and she must immediately restore it. Substitutive performance of the custodial duty is achieved through an order that

\footnotetext{
${ }^{73}$ Vestergaard (n 56).

${ }^{74}$ Coco v AN Clark Engineers Ltd (1969) RPC 41, 48, 49 (Megarry VC).

${ }^{75}$ AlB Group (UK) Plc v Mark Redler \& Co Solicitors [2014] UKSC 58; [2014] 3 WLR 1367.

${ }^{76}$ FHR European Ventures LLP v Cedar Capital Partners LLC [2014] UKSC 45; [2015] AC 250.

${ }^{77}$ L. Smith, 'W(h)ither Knowing Receipt?' (1998) 114 LQR 394, 395.

78 Mitchell \& Watterson (n 66) 129, 130; cited with approval in Arthur v AG of Turks and Caicos [2012] UKPC 30 [37] (Sir Terence Etherton).
} 
the defendant pay over the value of the property. No proof of breach of duty is required, and so the defendant's liability to pay is primary, rather than secondary. ${ }^{79}$ On a third, slightly different analysis, the defendant's liability to pay is regarded as responding to the breach of her primary custodial duty. ${ }^{80}$

Third, the idea of conscience does not mandate a specific level of knowledge which must be present before a moral obligation will arise. Most obviously, an individual's conscience may be said to be affected where she is consciously aware of all the relevant facts. sHowever, it is not linguistically inaccurate to say that her conscience is affected, even where she only has very limited knowledge, such as would prompt a reasonable person to make enquiries which would reveal the relevant facts. This knowledge makes it possible for her, through the process of moral reasoning, to work out what she ought to do, i.e., make further enquiries, which in turn would reveal the information necessary for her to decide how she ought ultimately to behave. In such a case, her conscience may still be said to be affected, albeit less strongly than in a case of actual knowledge.

The authorities support the view that the degree of knowledge necessary to trigger an equitable obligation is itself a question of principle, the answer to which depends on the nature of the duty and the defendant's specific circumstances. For example, the courts regard the defendant's conscience as sufficiently affected for the duty of confidence to arise if she has any one of the five levels of knowledge on the Baden Delvaux ${ }^{81}$ scale, i.e., if she knows enough to prompt the reasonable person to make enquiries which would reveal the information's confidential nature, but fails to make those enquiries herself. ${ }^{82}$ By contrast, the threshold of knowledge required to trigger the duties of trusteeship is higher, and varies according to the type of trust.

There has also been extensive debate about the degree of knowledge required to trigger a finding that the defendant is a knowing recipient of trust property. On the one hand, it has been said that the defendant 'cannot conscientiously retain' the property where she receives it with actual or constructive knowledge of the breach of trust, ${ }^{83}$ and, historically, the standard of knowledge required extended to all five Baden categories. ${ }^{84}$ On the other hand, it has been stated that to hold the defendant liable because she ought to know the relevant facts would be 'to disregard equity's concern for the state of the conscience of the defendant'. ${ }^{85}$ Such language tends to suggest that the idea of conscience is more closely associated with the first three categories on the Baden scale, and the preponderance of recent high level English authority supports the view that this level of knowledge is probably required. ${ }^{86}$ However, any conclusion about the requisite level of knowledge should be informed by relevant factors of principle and/or policy, such as the extent to which it is reasonable to expect a volunteer or a purchaser to make enquiries about the provenance of

\footnotetext{
${ }^{79}$ Mitchell \& Watterson (n 66) 123, 132, 135-136.

${ }^{80}$ E.g., J. Glister \& J. Lee, Hanbury \& Martin Modern Equity $\left(20^{\text {th }}\right.$ ed) (Sweet \& Maxwell 2015) [25-015].

${ }^{81}$ Baden v Société Générale pour Favouriser le Développement du Commerce et de 'I'Industrie en France SA [1993] 1 WLR 509 (Ch), 575-576 (Peter Gibson J).

${ }^{82}$ A $v$ v Guardian Newspapers (n 54) 281 (Lord Goff); Campbell v MGN Ltd (n 54) [14] (Lord Nicholls); Primary Group (UK) Ltd v Royal Bank of Scotland [2014] EWHC 1082 (Ch) [237], [240] (Arnold J).

${ }^{83}$ Belmont Finance Corporation v Williams Furniture Ltd (No. 2) [1979] Ch 250 (CA).

${ }^{84}$ Karak Rubber Co Ltd v Burden (No 2) [1972] 1 WLR 602 (Ch), 633 (Bingham LJ).

${ }^{85}$ Consul Development Pty Ltd v DPC Estates Pty Ltd (1975) 132 CLR 373, 410-411 (Stephen J); Re Montagu (n 65) 278 (Megarry VC); Havelock, 'The Transformation of Knowing Receipt' [2014] RLRev 1, 15; Snell's Equity (n 55) 242 [9-014].

${ }^{86}$ Re Montagu (n 65); BCCl v Akindele [2001] Ch 437 (CA), 455 (Nourse L); Arthur (n 78) [36]-[41].
} 
the property and subject her to a custodial obligation if she fails to do so. ${ }^{87}$ It is not, and should not be treated as, an inevitable conclusion arising from the language of conscience.

\section{UNCONSCIONABILITY AND MORAL FAULT IN THE BREACH OF EQUITABLE OBLIGATIONS}

The term 'unconscionable' is also sometimes used to describe the breach of an equitable obligation. Here, it signifies, retrospectively, that the defendant has breached an obligation which has both moral and legal significance. However, its invocation in this way may give rise confusion and legal uncertainty at doctrinal level if its explanatory limits are not properly understood and respected. Its use in the doctrine of knowing receipt illustrates this point well. $^{88}$

A knowing recipient is guilty of 'unconscionable conduct' if she retains the property. ${ }^{89}$ If the explanatory limits of unconscionability are properly understood, its invocation is not too problematic, as it simply reinforces the idea that her retention of the property despite her knowledge constitutes a breach of moral duty, which is enforceable in equity. But the language of unconscionability has also crept into the cause of action: the recipient will be liable if her state of knowledge is 'such as to make it unconscionable for [her] to retain the benefit of the receipt' of the trust property. ${ }^{90}$ It has been argued that the language of unconscionability obscures the question whether the defendant had sufficient knowledge to justify the imposition of a binding equitable duty, and shifts our focus to whether her conduct may be regarded as wrongful. ${ }^{91}$ In response, it might be said that this simply indicates that the defendant has enough knowledge to justify the imposition of the duty when she has enough knowledge to be morally guilty, and this is an issue that, given our capacity for moral understanding, we are all capable of answering.

In any event, if the correct analysis is that the defendant's liability takes the form of substitutive performance of a primary custodial obligation, ${ }^{92}$ the presence of the language of unconscionability in the cause of action is otiose and misleading insofar as it suggests that a breach of that obligation is a prerequisite to relief. Even if the recipient's liability is properly regarded as secondary in that it responds to a breach of a primary equitable obligation, the presence of the term 'unconscionable' still muddies the waters, as it may lead us to think that proof of conscious moral wrongdoing is required to justify a remedy for breach. Although it may be easy to infer bad faith from the defendant's failure to restore the property, ${ }^{93}$ all that need be proved is that her conscience is affected by factual knowledge, and this goes to the incidence of the duty in the first place, rather than to any question of breach. Once factual knowledge is established and the duty arises, the defendant may breach it either because she fails to understand morally that she ought not to keep the property for her own benefit, or because she understands this but decides to keep the property anyway. For this reason, it is fair to say that her liability for breach does not depend on deliberate or conscious moral

\footnotetext{
${ }^{87}$ E.g., Re Montagu (n 65) 277-282 (Megarry VC); cf Cowan de Groot Properties Ltd v Eagle Trust plc [1991] BCLC 1045 (Ch) 1109 - 1112 (Knox J); Arthur (n 78) [34]; M. Bryan, 'The Receipt-Based Constructive Trust: A Case Study of Personal and Proprietary Restitution in the Supreme Court' (1999) 37 Alta L Rev 73, 85; Havelock, The Transformation of Knowing Receipt (n 85) 16.

${ }^{88}$ P. Birks, 'Receipt' in P. Birks \& A. Pretto (eds), Breach of Trust (Hart 2002) 226.

${ }^{89}$ Arthur (n 78) [40] (Etherton LJ).

${ }^{90}$ Akindele (n 86), 455 (Nourse LJ); Arthur (n 78) [31].

${ }^{91}$ Havelock, 'The Transformation of Knowing Receipt' (n 85) 8, 10.

${ }^{92}$ As Mitchell \& Watterson ( $n$ 66) argue; Havelock (n 85) 11.

${ }^{93}$ As happened in Arthur (n 78) [40].
} 
wrongdoing. Her moral understanding is equally irrelevant to her liability for breach of fiduciary duty ${ }^{94}$ or the duty of confidence. ${ }^{95}$

It follows that if the language of unconscionability is to be used to signify that a breach of equitable obligation is also a breach of a moral duty, two things are necessary to avoid confusion and legal uncertainty at doctrinal level. First, we must disentangle the question of whether a duty arises in the first place from the question of breach. Whether the defendant's conscience is affected by knowledge of the relevant facts is relevant to the incidence of the duty, but the term 'unconscionable' adds little to our understanding of this point. It is better confined to a description of the defendant's moral fault in breaching the obligation. And if it is to be used in this latter sense, we must be clear as to whether it is to be used generally, to remind us that every breach of an equitable obligation is a breach of moral duty, or, more narrowly, to describe a specific type of breach of equitable obligation, i.e., where the defendant understands morally that she is doing wrong.

\section{CONSCIENCE AND THE RESTRICTION OF LEGAL RIGHTS THROUGH PRIMARY LIABILITIES}

The courts also use the language of conscience and unconscionability in accordance with its ordinary meaning to indicate that the moral quality of the defendant's behavior is relevant to the imposition of a primary common law or equitable liability, which restricts the exercise of her legal rights. Three examples are considered below: restitution and rescission for defective transfers, and estoppel.

\section{A. Restitution for Defective Transfers}

\section{Meaning}

The English courts have used the language of conscience to indicate that a defendant who (knowingly) retains a mistaken payment is morally at fault. ${ }^{96}$ More recently, the Australian courts have suggested that the common law action for money had and received is based on 'good conscience' and has equitable roots. ${ }^{97}$ In their view, it has been absorbed into the common law, so as to prevent the exercise of a legal right where its exercise 'would constitute unconscionable conduct'. ${ }^{98}$ Thus, recovery of a mistaken payment is said to depend on whether the defendant's retention of it would be 'against conscience'. ${ }^{99}$ Furthermore, the change of position defence is said to be 'grounded in that body of equitable doctrine that prevents the unconscientious assertion of what are said to be legal rights', so that the question is 'whether it would be unconscionable for a recipient who has changed its position on the faith of the receipt to be required to pay'. ${ }^{100}$ This language suggests that the defendant breaches a moral duty if she insists on her legal title to the money despite the mistake.

\footnotetext{
${ }^{94}$ Boardman v Phipps [1967] 2 AC $46(\mathrm{HL})$.

${ }^{95}$ Vestergaard (n 56).

${ }^{96}$ E.g., Moses v Macferlan (1760) 2 Burr 1005; 97 ER 676; Kelly v Solari (1841) 9 M \& W 54; 152 ER 24.

${ }^{97}$ Australian Financial Services and Leasing Pty Ltd v Hills Industries Ltd [2014] HCA 14, [65], [68], [74] (Hayne, Crennan, Kiefel, Bell and Keane JJ).

98 Roxborough v Rothmans of Pall Mall Australia Ltd [2001] HCA 68; (2001) 208 CLR 516, 555 (Gummow J).

${ }^{99}$ Hills (n 97) [65].

100 ibid [86], [88].
} 


\section{Explanatory role}

There is strong academic support for the view that personal claims arising out of defective transfers are free-standing liabilities rather than duty-based claims. ${ }^{101}$ This leads Smith to argue that the explanation of such claims cannot be 'about the defendant's moral obligations. ${ }^{102}$ In his view, restitution for defective transfers is more properly justified by the fact that relief is necessary to deal with some problems caused by the strict legal rules on title, e.g., where the defendant obtains legal title to the money even though the claimant did not properly intend her to have it. ${ }^{103}$ This must be right. The common-law action for money had and received has never been regarded as fault-based, ${ }^{104}$ and the cause of action arises even if the defendant was wholly unaware of the mistake at the date of receipt. Because the claim arises even if the defendant was wholly unaware of the mistake at the date of receipt, her liability cannot be said to depend on a failure to comply with a moral or legal duty to make restitution, and thus the language of conscience tells us nothing about how that liability arises.

It follows that language of conscience tells us nothing about why the defendant's liability to make restitution arises, it does help us to understand that the extent of the defendant's liability is informed by the extent to which she owes the claimant a moral duty in respect of the money. For example, in the case of a mistaken payment, the fact that the defendant acquired legal title to the money on receipt is inconsistent with any legal duty to return it before the date of judgment, ${ }^{105}$ but there is nothing to prevent a moral duty arising in the meantime. If the defendant learns of the claimant's mistake and her conscience is affected by that knowledge, she comes under a moral duty not to use or dispose of the money any further for her own benefit. ${ }^{106}$ Before then, she is arguably subject only to a moral liability, ${ }^{107}$ in the sense that she bears the moral risk that the claimant did not consent properly to the payment ${ }^{108}$ and may demand that she repay it or an equivalent sum. This is reflected in the change of position defence, which permits her to assert legal title to money she spends before acquiring such knowledge. If she pays some of the money away after she acquires knowledge, ${ }^{109}$ she breaches a moral duty by dissipating it and becomes personally liable to make restitution in full. Thus, the language of conscience reminds us that the extent of the defendant's ultimate liability will be commensurate with the value of the enrichment surviving at the date on which she becomes subject to a moral duty towards the claimant.

In addition, once the defendant acquires knowledge of the mistake, equity recognises the defendant's moral duty and immediately underwrites it by treating the defendant as a non-express trustee of the money. ${ }^{110}$ This means that from the date of knowledge, the defendant is subject to the core trust obligation not to dispose of the property other than for

\footnotetext{
${ }^{101}$ Smith (n xx) 158, 164-5; Jaffey ( $\mathrm{xx}$ ) 24-5.

102 Ibid, 165 n33.

103 A. Burrows, The Law of Restitution (OUP 2010) 203-204.

${ }^{104}$ Sir William Evans, 'An Essay on the Action for Money had and Received (1802)' (1998) 6 RLR 2.

${ }^{105}$ Smith (n xx) 172, 173, 177.

${ }^{106}$ Smith (ibid) accepts that a duty of this kind may arise.

${ }^{107}$ On the use of the Hohfeldian classification scheme to describe moral relations, see: Kramer, Rights Without Trimmings [complete citation].

108 Jaffey (n xx) 25.

${ }^{109}$ Niru Battery Manufacturing Company v Milestone Trading Ltd [2003] EWCA Civ 1446; [2004] QB 985, [156][158] (Clarke LJ).

${ }^{110}$ Westdeutsche (n 60) 715 (Lord Browne-Wilkinson); Papamichael (n xx).
} 
the benefit of the claimant. ${ }^{111}$ As in the case of trust obligations generally, here the language of conscience helps to explain how the defendant's obligation arises.

\section{B. Rescission for Defective Transfers}

\section{Meaning}

The availability of rescission for unilateral mistake in equity ${ }^{112}$ has been said to depend on whether it is 'unconscionable for the non-mistaken party to insist that the contract be performed. ${ }^{113}$ For these purposes, unconscionability presupposes some 'impropriety' on her part at the time the contract was formed, such as deliberately not alerting the mistaken party to her mistake. ${ }^{114}$ The clear implication is that the defendant's knowledge of the claimant's mistake triggers a moral duty to correct it, the breach of which justifies the defendant's liability.

It is said to be 'unconscientious' ${ }^{115}$ for the defendant to avail of her contractual rights after making an innocent misrepresentation, either because she ought reasonably to have known that her statement was untrue when she made it, or because it is 'a moral delinquency' for her to take the benefit of the contract once she becomes aware of the falsity of her statement. ${ }^{116}$ This language suggests that the fact that the defendant has reason to know whether her statement was true is sufficient to subject her to a moral duty not to mislead the claimant; further or alternatively, that when the defendant acquires knowledge that her statement was false, she comes under a moral duty not to exercise her legal rights against the claimant. Fraudulent misrepresentation is also sometimes referred to as an example of unconscionability which affects the defendant's conscience. ${ }^{117}$

In cases of relational undue influence, reference has been made to 'the obligations which are imposed on the conscience of the donee by the principles of this court', ${ }^{118}$ which may include 'an equitable duty' to encourage the claimant to take independent advice. ${ }^{119}$ It is also said that equity intervenes to relieve for undue influence 'whenever one party has acted unconscionably by exploiting the influence to direct the conduct of another which he has obtained from the relationship between them. ${ }^{120}$ Proof that the defendant was aware of her influence over the claimant is unnecessary, though it may be implicit. ${ }^{121}$ Here, the language of conscience suggests a moral duty to ensure the claimant receives advice and/or not to exploit her bargaining weakness.

The language of conscience is used the same way in relation to unconscionable bargains. For example, it has been held that if the defendant knows of the claimant's special

\footnotetext{
${ }^{111}$ ITS v Noble ( $\mathrm{nxx}$ [ [78], [81] (Lloyd LJ).

${ }^{112}$ The availability of rescission for unilateral mistake in English law has been in doubt since the decision in Great Peace Shipping Ltd v Tsavliris Salvage (International) Ltd [2002] EWCA Civ 1407; [2003] QB 679.

${ }^{113}$ Chwee Kin Keong v Digilandmall.com Pte Ltd [2005] 1 SLR 502 (SCA) [73], [80].

114 ibid; Taylor v Johnson (1982-1983) 151 CLR 422 (HCA), 431.

${ }^{115}$ Torrance v Bolton (1872) LR 8 Ch 118 (CA), 124 (James LJ).

${ }^{116}$ Redgrave v Hurd (1881) 20 Ch D 1 (CA), 12-13 (Jessel MR).

${ }^{117}$ Hart v O'Connor [1985] AC 1000 (PC), 1024 (Lord Brightman).

${ }^{118}$ Allcard v Skinner (1887) 35 Ch D 145 (CA), 190 (Bowen LJ).

119 Liddle v Cree [2011] EWHC 3294, [83], [84] (Briggs J).

${ }^{120}$ National Commercial Bank (Jamaica) Ltd v Hew's Executors [2003] UKPC 51, [28], [33] (Lord Millett).

${ }^{121}$ P. Birks \& N. Chin, 'On the Nature of Undue Influence' in J. Beatson \& D. Friedman (eds), Good Faith and Fault in Contract Law (OUP 1995) 85.
} 
disability, she "has an obligation to say to the weaker party: no, I cannot in all conscience accept the benefit of this transaction in these circumstances either at all or unless you have full independent advice. ${ }^{122}$ If she proceeds with the transaction without doing so, and the transaction is 'manifestly unfair' to the claimant, her conduct may be described as 'unconscientious', ${ }^{123}$ i.e., she has breached her moral duty. More recent English and Australian authority suggests that a deliberately exploitative intention ${ }^{124}$ or a 'predatory state of mind $^{125}$ is now required before the defendant's conduct will be described as unconscionable.

Finally, a threat to do something lawful will only constitute illegitimate pressure for the purposes of the common law doctrine economic duress ${ }^{126}$ if the defendant's conduct can be described as 'morally or socially unacceptable', ${ }^{127}$ or 'immoral or unconscionable'. ${ }^{128}$ The authorities suggest that the defendant's conduct will be morally unacceptable if she acts with an improper motive, i.e., by deliberately placing the claimant in a position where she has no realistic option but to agree to a bargain, which the defendant knows is inimical to the claimant's interests. ${ }^{129}$

\section{Explantory role}

It seems right to say that a claim for rescission arising out of a defective transfer takes the form of a primary liability. Although in some cases the defendant's conduct will involve a breach of legal duty - e.g., where she is also guilty of deceit (fraudulent misrepresentation) or intimidation (an illegitimate threat to do something unlawful) - the fact that the courts are sometimes prepared to grant rescission for lawful act duress at common law ${ }^{130}$ suggests that a breach of legal duty is not always necessary. Equitable rescission does not depend on a breach of prior duty either. It has been suggested that the conduct involved in undue influence involves a breach of an equitable duty to protect her from harm, ${ }^{131}$ and that at least when the defendant has been at fault, ${ }^{132}$ it should be treated as an equitable wrong. However, recent authority does not support this view; ${ }^{133}$ and it has been held that the

\footnotetext{
${ }^{122}$ Bowkett v Action Finance Ltd [1992] 1 NZLR 399, 457 (Tipping J); Baker v Monk (1864) 4 De G \& S 388, 394; 46 ER 968, 971.

${ }^{123}$ Commercial Bank of Australia Ltd v Amadio (1983) 151 CLR 447 (HCA), 474, 478, 479 (Deane J).

${ }^{124}$ Alec Lobb (n xx).

${ }^{125}$ Kakavas (n 33) [161].

${ }^{126}$ R. Ahdar, 'Contract Doctrine, Predictability and the Nebulous Exception' (2014) 73 CLJ 39 doubts whether a threat to do something lawful will ever constitute illegitimate pressure absent previous unlawful conduct, but Tam Tak Chuen v Khairul bin Abdul Rahman [2009] 2 SLR 240 (SCA) [57]-[59] suggests otherwise.

${ }^{127}$ CTN Cash \& Carry Ltd v Gallagher Ltd [1994] 4 All ER 714 (CA), 719 (Steyn LJ).

${ }^{128}$ Alf Vaughan \& Co Ltd (In Receivership) v Royscot Trust Plc [1999] 1 All ER (Comm) 856 (Ch), 863 (Judge Rich QC); Progress Bulk (n 135) [22] (Cooke J).

${ }^{129}$ Tam Tak Chuen v Khairul bin Abdul Rahman [2009] 2 SLR 240 (SCA) [57]-[59]; Borrelli (n xx) [28]-[35]; Progress Bulk (n xx) [39]-[40].

${ }^{130}$ E.g., Tam Tak Chuen v Khairul bin Abdul Rahman ( $\mathrm{xx}$ ).

${ }^{131}$ Lloyd's Bank Ltd v Bundy [1975] QB 326 (CA), 341 (Sir Eric Sachs); Etridge ( $\mathrm{nx}$ ) [103] (Lord Hobhouse); P. Millett, 'Equity's Place in the Law of Commerce' (1998) 114 LQR 214, 219; R. Bigwood, 'Contracts by Unfair Advantage: from Exploitation to Transactional Neglect' (2005) 25 OJLS 65; M. Chen-Wishart, 'Undue Influence: Beyond Impaired Consent' (n xx) 217, 220-221.

${ }^{132}$ L. Ho, 'Undue Influence and Equitable Compensation' in F. Rose (ed), Restitution and Equity: Vol 1: Resulting Trusts and Equitable Compensation (Mansfield Press 2000) 197; and G. Virgo, 'The Role of Fault in the Law of Restitution' in A. Burrows and A. Rodger (eds), Mapping the Law (OUP 2006) 99.

${ }^{133}$ Agnew v Lansforsakringsbolagens AB [2001] 1 AC 223 (HL), 265 (Lord Millett).
} 
purpose of relief for undue influence is to prevent the unjust enrichment of the defendant. ${ }^{134}$ Even though recent authority indicates that the Australian High Court may be prepared to recognise the conduct involved in unconscionable bargains and lawful act duress as an equitable wrong ${ }^{135}$ (i.e., a breach of a primary equitable obligation), they have yet to give a reliable indication of what this would entail, ${ }^{136}$ and English law has yet to take this step. In any case, the availability of equitable rescission for innocent misrepresentation clearly demonstrates that a prior breach of equitable duty is unnecessary to ground relief. All that is necessary is that the defendant caused the impairment of the claimant's consent. ${ }^{137}$ The fact that rescission is available even though she neither knew nor had reason to know her statement was false when the contract was formed suggests that she cannot have been under any equitable or moral duty at that time. The nature of an order for rescission also supports this view. It does not replicate or underwrite a pre-existing duty. Rather, it excuses the claimant from performance of her legal obligations, and disables ${ }^{138}$ the defendant from exercising her legal rights.

The explanatory role of the language of conscience at doctrinal level in relation to rescission for defective transfers has been a matter of debate. Certainly, its presence suggests that the courts regard a breach of moral duty by the defendant as doctrinally relevant to the availability of rescission. In cases of unilateral mistake, unconscionable bargains and lawful act duress, it may be argued that if the defendant knows of the problem with the claimant's consent, this is sufficient to subject her to a moral duty not to go ahead with the contract. Undue influence might be explained in the same way on the basis that the defendant's implicit knowledge of her position of influence is also sufficient to generate such a duty. ${ }^{139}$

On this analysis, the language of conscience and unconscionability might be said to do some explanatory work by reminding us that a breach of prior moral duty by the defendant is necessary before relief in the form of rescission is available. ${ }^{140}$ However, this analysis cannot adequately take account of rescission for innocent misrepresentation, which does not require proof of knowledge and therefore cannot depend on the defendant's breach of a preexisting moral duty. Rather, the claimant is entitled to rescind because her consent was impaired or distorted, and the defendant (innocently) caused that impairment. It follows that in such cases, the language of conscience tells us nothing about the cause of action ${ }^{141}$ or why the defendant's liability arises. Rather, it emphasises that at the date of judgment, it would now be a breach of moral duty for her to insist on her contractual rights, and thus she will not be permitted to do so.

The alternative argument is that rescission for defective transfers responds to the problem with the claimant's consent, and the existence and/or breach of a moral duty by the

\footnotetext{
${ }^{134}$ Hart v Burbidge [2014] EWCA Civ 992, [43] (Vos LJ).

${ }^{135}$ ANZ Banking Group Ltd v Karam [2005] NSWCA 344, [61], [66] (suggests the merger of lawful act duress into the doctrine of unconscionable dealing); Kakavas v Crown Melbourne Ltd [2012] VSCA 95, [10]-[11] (Mandie JA); Kakavas (n 33) [161].

${ }^{136}$ M. Bryan, 'Unconscionable Conduct as an Unjust Factor' in S. Degeling and J. Edelman (eds), Unjust Enrichment in Commercial Law (Thomson 2008) 303.

${ }^{137}$ P. Birks, 'Undue Influence as Wrongful Exploitation' (2004) 120 LQR 34, 36.

${ }^{138}$ T. Yeo, 'Unilateral Mistake: Five Degrees of Fusion of Common Law and Equity' [2004] Sing JLS 227, 231, n34.

${ }^{139}$ R. Bigwood, 'Contracts by Unfair Advantage: from Exploitation to Transactional Neglect' (2005) 25 OJLS 65.

${ }^{140}$ Thus, Bigwood argues that the idea of conscience plays a corrective justice function in contract law: [xx]

${ }^{141}$ Birks and Chin $[\mathrm{xx}]$
} 
defendant is incidental to the grant of relief. Proponents of this view suggest that by analogy with restitution for mistaken payments, rescission for unilateral mistake may be explained on the ground of lack of consent, but that where there is a contract, relief is restricted 'in the interest of upholding bargains ${ }^{142}$ to cases where the defendant knows about the mistake and cannot reasonably rely on the appearance of a consensus. In cases of undue influence the fact that claimant's 'decision-making capacity was crippled by undue influence' is sufficient to justify relief. ${ }^{143}$ Either the defendant's implicit knowledge of the problem with consent or the fact that her relationship with the claimant caused it is sufficient to make it unreasonable for her to rely on the appearance of consensus. ${ }^{144}$ Although knowledge is a necessary element of the cause of action in cases of unconscionable bargains, this is explained away as merely displacing the defendant's interest in security of receipt. ${ }^{145}$ It has also been argued that rescission for lawful act duress may be justified by reference to consent alone, ${ }^{146}$ and again, the defendant's knowledge of the claimant's lack of choice goes simply to the question whether it is reasonable for the defendant to rely on the lack of consensus.

On the consent-based analysis, it follows that even if the defendant's knowledge of the problem with consent gives rise to a moral duty, the existence and breach of any such duty by the defendant is incidental to the grant of relief, and so the language of conscience and unconscionability does no explanatory work at all. However, the courts clearly regard impaired consent as insufficient to justify relief in cases of unconscionable bargains ${ }^{147}$ and lawful act duress, perhaps because as a matter of policy sometimes actors must expect their consent to transactions to be 'legitimately' impaired, ${ }^{148}$ so that a breach of moral duty by the defendant is required before any relief will be granted. If this is right, then it is difficult to argue that the language of conscience and unconscionability is entirely redundant in such cases.

Ultimately, the extent to which the language of conscience is regarded as doing any explanatory work depends on one's view as to the proper justification for rescission. On the one hand, the ubiquity of the language of conscience tends to suggest that the courts regard a prior or prospective breach of moral duty by the defendant as relevant to the restriction of the defendant's legal rights through rescission. On the other hand, if the consent-based analysis of rescission for defective transfers is correct in principle, the language of conscience explains nothing about how or why the defendant's liability arises. On this analysis, its invocation is open to criticism on the basis that it tends to suggest that relief depends on the defendant's wrongdoing, ${ }^{149}$

However, it does help to explain how the defendant may become a non-express trustee of any property received under the contract. ${ }^{150}$ As in the case of trust obligations generally, the language of conscience helps us to understand how this obligation arises. Once the defendant's conscience is affected by knowledge that the claimant's consent was defective, arguably she comes under a moral duty not to retain or dispose of the property for

\footnotetext{
142 ibid 265.

${ }^{143}$ Birks, 'The Role of Fault' ( $\left.\mathrm{n} x \mathrm{x}\right) 262$.

${ }^{144}$ Birks, 'Undue Influence' (n 137) 36

145 Rickett ( $\mathrm{nxx}$ ).

${ }^{146}$ S. Smith, 'Contracting Under Pressure: A Theory of Duress' (1997) 56 CLJ 343, 344.

${ }^{147}$ Acknowledged by P. Birks, 'The Role of Fault in the Law of Unjust Enrichment' in W. Swadling \& G. Jones (eds), The Search for Principle (OUP 1999).

148 Barton v Armstrong [1976] AC 104, 121 (Lords Wilberforce and Simon).

${ }^{149}$ Birks, 'The Role of Fault' ( $\mathrm{nx}$ ); Virgo, 'The Role of Fault' ( $\mathrm{nxx}$ ) 99.

${ }^{150}$ Mothew (n 62).
} 
her own benefit. The date on which this duty arises varies. In a case of deceit, it arises on or before the date the contract is formed, whereas in a case of innocent misrepresentation it may arise only at the date of election. In all cases, however, the courts postpone the enforcement of the moral duty as a positive equitable obligation to the date of election. ${ }^{151}$ Various reasons have been suggested for this postponement, i.e., that it protects third parties, ${ }^{152}$ and avoids any inconsistency between the equitable obligation and the defendant's contractual rights ${ }^{153}$ in the meantime.

\section{Estoppel}

\section{Meaning}

The language of conscience and unconscionability is widely used in the common-law doctrine of estoppel by convention and the equitable doctrines of promissory and proprietary estoppel. An estoppel by convention arises where it would be unconscionable for one of the parties to resile from a shared assumption, which formed the basis of their dealings (but which does not reflect their strict legal rights). ${ }^{154}$ The court looks at the parties' position at the date of the hearing ${ }^{155}$ and asks whether it would now be unconscionable for $A$ to resile from the shared assumption, and this depends on whether B would suffer detriment, ${ }^{156}$ or $A$ has gained a benefit from the parties' reliance on it. ${ }^{157}$ If so, then $A$ is precluded from denying the truth of the facts underlying the assumption. ${ }^{158}$

The language of unconscionability is also used in equitable estoppel claims arising from promises to describe the fact that it would be morally unacceptable for $A$ to exercise her strict legal rights against $\mathrm{B} .{ }^{159}$ The moral tone is clear: the term 'unconscionable' refers to 'one party "ought not, in conscience as between [the parties] to be allowed" to do' and whether her insistence upon the strict legal position 'affronts ordinary minimum standards of fair dealing. ${ }^{160}$ For these purposes, a promise by $A$ that she will not exercise her strict legal rights against her, ${ }^{161}$ or that she will grant her an interest in $A^{\prime}$ s land, ${ }^{162}$ and detrimental reliance by $B$, are required. If they are proved, it becomes unconscionable, i.e., a breach of moral duty for $A$ to resile from the promise and exercise her legal rights without making good any detriment to $B$ that may result. ${ }^{163}$ Proprietary estoppel by acquiescence arises where $A$ allows $B$ to act on a belief, which $A$ knows to be mistaken, that by her actions she as acquired or is

\footnotetext{
${ }^{151}$ Although the claimant's proprietary interest operates retrospectively from the date of election for the purpose of tracing into substitute assets in the defendant's hands: Mothew $(\mathrm{n} x \mathrm{x})[\mathrm{xx}]$.

152 lbid.

${ }^{153}$ E. Bant, 'Reconsidering the Role of Election in Rescission' (2012) 32 OJLS 467, 476.

${ }^{154}$ Norwegian American Cruiser A/S v Paul Mundy Ltd (The Vistafjord) [1988] 2 Lloyd's Rep 343 (CA).

${ }^{155}$ PW v Milton Gate Investments Ltd [2003] EWHC 1994 (Ch); [2004] Ch 142 [38] (Neuberger J).

${ }^{156}$ Benchdollar (n 166) [55] (Briggs J).

157 ibid.

${ }^{158}$ Amalgamated Investments (n 167) 126 (Eveleigh LJ).

${ }^{159}$ Cobbe v Yeoman's Row Management Ltd [2008] UKHL 55, [2008] 1 WLR 1752 [98] (Lord Walker); Kim v Chasewood Park Residents Ltd [2013] EWCA Civ 239; [2013] HLR 24 [41] (Patten L).

${ }^{160}$ Verwayen (n 34) 441 (Deane J).

${ }^{161}$ B. McFarlane, 'Understanding Equitable Estoppel: From Metaphors to Better Laws' (2013) 66 CLP 267, $281-$

282 suggests that there are other strands of promissory estoppel, which are not considered here.

${ }^{162}$ Suggitt v Suggitt [2012] EWCA Civ 1140.

${ }^{163}$ Waltons Stores (Interstate) Ltd v Maher (1988) 165 CLR 387, 424 (Brennan J), 407 (Mason CJ and Wilson CJ); Suggitt v Suggitt ( $\mathrm{xx}$ ) (Arden LJ); Kim v Chasewood Park Residents ( $\mathrm{xx}$ ).
} 
in the process of requiring a right over $A^{\prime}$ s land. ${ }^{164}$ If $A$ fails to correct $B^{\prime}$ s mistake, it is regarded as unconscionable, or morally unacceptable, for $A$ to insist on her legal rights. ${ }^{165}$

\section{Explanatory role}

For $A$ to be bound by an estoppel by convention, she must have assumed an element of responsibility, 'in the sense of conveying to $[B]$ an understanding that [she] expected $[B]$ to rely on it', ${ }^{166}$ but the estoppel may arise even where both parties share the mistaken belief that the assumption is true. ${ }^{167}$ Even if the effect of the parties' communications is to subject A to a positive moral duty not to resile from the assumption, ${ }^{168}$ the common law does not immediately underwrite such a moral duty with a contiguous legal duty to abide by the assumption, the breach of which triggers the estoppel. Therefore, estoppel by convention may properly be described as a primary liability rather than a duty-based claim.

Views differ as to whether equitable estoppel arising from promises is a duty-based claim or another example of a primary liability. Samet argues that in cases of proprietary estoppel by promise, relief responds to a breach by $A$ of a moral duty, which arises when she makes her promise to grant $B$ an interest in land. The duty is not to honour the promise, but to warn B not to rely on it or, failing that, to compensate her for any detrimental change of position she incurs by relying on it. ${ }^{169}$ The breach of this duty involves 'a moral wrong that taints [A's] conscience', ${ }^{170}$ which requires $A$ to compensate $B$ to the extent of her reliance loss only. ${ }^{171}$ Samet does not expressly state whether she regards the moral duty as a primary equitable duty, but her analysis would seem to suggest this. If so, the language of unconscionability would play a similar role here to that which it plays in relation to the breach of other primary equitable obligations, and this analysis could also potentially apply to cases of promissory estoppel.

McFarlane argues that the need for detrimental reliance to be proved before relief will be granted, and the fact that even then $A^{\prime}$ 's promise is not inevitably enforced, ${ }^{172}$ suggests that neither form of equitable estoppel responds to the breach of a pre-existing equitable duty by $A$ to keep her promise. In his view, both doctrines impose primary liabilities to address a potential injustice caused by the unmitigated application of the common-law rules of property and contract. ${ }^{173}$ Even if the making of the promise by A generates a moral duty to honour it, ${ }^{174}$ the courts do not underwrite this moral duty as a positive equitable obligation:

\footnotetext{
${ }^{164}$ Ramsden v Dyson (1866) LR 1 HC 129, 140-141; Willmott v Barber (1880) 15 Ch D 96, 105-106.

${ }^{165}$ Taylor's Fashions Ltd v Liverpool Victoria Trustees Co Ltd [1982] QB 133, 148, 151-152 (Oliver J).

${ }^{166}$ The August Leonhardt [1985] 2 Lloyd's Rep 28 (CA), 34-35; HM Revenue \& Customs v Benchdollar Ltd [2009] EWHC 1310 (Ch) [55] (Briggs J).

${ }^{167}$ Amalgamated Investment \& Property Co Ltd (in Liquidation) v Texas Commercial International Bank Ltd [1982] QB 84 (CA).

${ }^{168}$ Verwayen (n 34), 440-445 (Deane J), 413 (Mason CJ).

169 I. Samet, 'Some Strings Attached: The Morality of Proprietary Estoppel' in J. Penner \& H. Smith (eds), The Philosophical Foundations of Property Law (OUP 2013), 128-129

170 ibid 129.

171 ibid 153.

172 McFarlane, 'Understanding Equitable Estoppel' (n 161) 287; B. McFarlane, 'Equitable Estoppel as a Cause of Action: Neither One Thing Nor One Other' in A. Dyson, J. Goudkamp \& F. Wilmot-Smith (eds), Defences in Contract (Hart 2017) 13.

${ }^{173}$ McFarlane, 'Understanding Equitable Estoppel' (n 161) 293-294; McFarlane, 'Equitable Estoppel as a Cause of Action' (n 172) 16-19.

174 On the binding nature of promises: J. Raz, 'Promises in Morality and Law' (1982) 95 Harv L Rev 916.
} 
to do so would conflict with the common-law rules of contract. ${ }^{175}$ On this analysis, whilst it may be a breach of moral duty for A not to honour her promise, the breach only becomes unconscionable in a legally significant sense in the light of what has happened since A made her promise. Thus, the language of unconscionability describes the fact that it would now be a breach of moral duty for $A$ to resile from it. ${ }^{176}$ If it is right that estoppel by convention and equitable estoppel arising from a promise are primary liabilities, the language of conscience and unconscionability does not do the same explanatory work that it does in relation to equitable obligations. Rather, it unifies and confirms 'the other elements of the cause of action', ${ }^{177}$ by emphasizing that if they are established, it will now be a breach of moral duty for $A$ to exercise her legal rights.

Samet argues that proprietary estoppel by acquiescence is a duty-based claim. In her view, once $A$ learns that $B$ is incurring detriment in the belief that she has or is thereby acquiring an interest in A's land, she comes under a positive equitable duty actively to disabuse $B$ of her mistake and state her adverse title. ${ }^{178}$ She may discharge this duty by informing $B$ of her contrary rights, and authority suggests that if she does this it will not be unconscionable for her to insist on those rights. ${ }^{179}$ Absent knowledge, however, no duty arises, and it will not be unconscionable for $A$ to insist on her legal rights. ${ }^{180}$ If this analysis is correct (and authority seems to support it ${ }^{181}$ ), the language of conscience plays the same explanatory role here that it plays in relation to other equitable obligations.

\section{THE SIGNIFICANCE OF THE LANGUAGE OF CONSCIENCE}

The language of conscience in private law is not a term of art. Rather, it is used in accordance with its ordinary meaning to explain how moral duties arise and to describe moral fault in the breach of such duties. The presence of this language in the context of equitable obligations draws our attention to the moral significance of factual knowledge as a prerequisite to their recognition and enforcement. In doing so, it reveals that equity requires that defendants can engage in moral reasoning before it will compel them to act in a particular way, and it suggests that when the courts give effect to equitable obligations, they are directly enforcing moral duties. Therefore, the language of conscience may be said to have some explanatory significance in relation to equitable obligations, albeit at a very general level.

In the context of primary liabilities, the language of conscience indicates that the courts are reluctant to curtail the defendant's legal rights unless there are good moral reasons for doing so, e.g., because she breached a moral duty in the acquisition of those rights or it would now be a breach of moral duty for her to exercise them fully. However, as primary liabilities never depend on the existence and breach of a pre-existing legal duty, and rarely, if ever, depend on the existence and breach of a pre-existing moral duty, the language of conscience does little, if any explanatory work, in helping us to understand how primary liabilities arise. However, sometimes it points to the moral limits of the defendant's liability

\footnotetext{
${ }^{175}$ McFarlane, 'Equitable Estoppel as a Cause of Action' (n 172).

${ }_{177}$ McFarlane, 'Equitable Estoppel as a Cause of Action' (n 172).

${ }^{177}$ Cobbe v Yeoman's Row Management Ltd [2008] UKHL 55, [2008] 1 WLR 1752 [92] (Lord Walker).

${ }^{178}$ I. Samet, 'Proprietary Estoppel and Responsibility for Omissions' (2015) 78 MLR 85.

${ }^{179}$ Blue Haven Enterprises Ltd v Tully [2006] UKPC 17, [25]-[28] (Lord Scott).

${ }^{180}$ Taylors Fashions (n xx) 155-157 (Oliver J).

${ }^{181}$ Ramsden v Dyson (1866) LR 1 HC 129, 140-1 (Lord Cranworth); Willmott v Barber (1880) 15 Ch D 96, 105106 (Fry J); Taylor's Fashions (n xx) 147 (Oliver J).
} 
(e.g., in cases of restitution), and, as in the case of equitable obligations generally, it has a role to play in explaining how non-express trusts arise after defective transfers.

Whether the limited explanatory work done by conscience is to be regarded as valuable must depend, at least in part, on the proper relationship between law and morality. A full exploration of this question is beyond the scope of this article. However, for the reasons which follow, it is submitted that the language of conscience does have a valuable role to play in private law, so long as its explanatory limits are properly understood and respected.

Even a positivist such as Hart accepts that ' $[1] \mathrm{n}$ all communities, there is a partial overlap in content between legal and moral obligation' ${ }^{182}$ and the development of law has been 'profoundly influenced both by the conventional morality and ideals of particular social groups' and by enlightened moral criticism. ${ }^{183}$ He also takes the view that a legal system may be rendered more stable to the extent to which the law reflects morality. ${ }^{184}$ It is therefore arguable that there are good reasons for treating the law and morality as mutually reinforcing, rather than entirely separate, 'normative domains'. ${ }^{185}$ Thus, to the extent that the language of conscience indicates that the courts are replicating moral standards which apply outside the law, arguably this is no bad thing.

Furthermore, although the language of conscience is sometimes criticised for inviting judicial moral subjectivism, ${ }^{186}$ the reality is that when judges make decisions, they are often making moral value judgments anyway, which are based on 'normative practices and understandings that already exist in society and outside the law. ${ }^{187}$ Dworkin suggests that even when working from first principles, judges perceive themselves to be elucidating and interpreting external standards of morality 'presupposed by the laws and institutions of the community'. ${ }^{188}$ Of course, they may be wrong (or misleading us) about what they are in fact doing, and it is difficult to argue that subjectivism can be avoided completely whenever opentextured concepts such as conscience, or reasonableness, are invoked. However, that may be as much to do with the outer limits of the doctrine of precedent, as with the language of conscience per se.

Arguably, as Harding has suggested, the language of conscience can play a valuable 'expressive' ${ }^{189}$ role in private law. No system of law can anticipate every eventuality, and each requires an adjustment mechanism to protect its formal rules from being opportunistically exploited. In English private law, it is generally equity which performs this function by acting as a gloss or supplement to the common law. ${ }^{190}$ There is nothing new in this idea, nor in the idea that the adjustment of the rules should take place by reference to extra-legal standards. ${ }^{191}$ Indeed, Henry Smith has recently argued that there are good economic reasons why equity should operate in this way. ${ }^{192}$ Where the language of

\footnotetext{
182 H.L.A. Hart, The Concept of Law [complete reference] 171.

183 Ibid 185, 204.

184 Ibid 204.

185 P. Cane, Responsibility in Law and Morality (Hart 2002) 6-12.

${ }^{186}$ Birks ( $\mathrm{nxx}$ ).

${ }^{187}$ Webb (n xx) 25, n38.

${ }^{188}$ R. Dworkin, Taking Rights Seriously (Harvard University Press 1978) 154, 156.

${ }^{189}$ M. Harding, 'Equity and the Rule of Law' (2016) 132 LQR 278, 286.

${ }^{190}$ F. Maitland, Lectures on Equity (OUP 1909) 18-19.

${ }^{191}$ E.g., Aristotle's idea of epieikia: see D. Klimchuk, [complete title] in L. Austin \& D. Klimchuk (eds), Private Law and the Rule of Law (Oxford University Press 2014) [xx].

${ }^{192}$ H.E. Smith, 'Property, Equity, and the Rule of Law' in L. Austin \& D. Klimchuk (eds), Private Law and the Rule of Law (Oxford University Press 2014) 232-233 suggests that this is one of the general functions of equity.
} 
conscience appears in common law and equitable doctrine, it signifies that the formal rules are being (or have been) adjusted for reasons which make moral sense. For example, its use in the context of primary common law and equitable liabilities indicates that the courts are adjusting the defendant's strict legal rights for good moral reasons, which we are all capable of understanding. This conveys the message that the courts are concerned not just with what the law says, but also with what Gardner describes as its 'moral clarity'. ${ }^{193}$

As far as obligations are concerned, it is true to say that not all moral duties are enforced as legal and equitable obligations, ${ }^{194}$ and views differ as to whether legal obligations always and invariably give effect to moral duties. ${ }^{195}$ However, if the argument that the language of conscience strongly suggests that equitable obligations underwrite and enforce moral duties is accepted, then when such an obligation is imposed, the language of conscience conveys the message that the defendant is being compelled to do she 'really ought to do', and not simply what she 'ought to do according to law' ${ }^{196}$ Furthermore, because the defendant will not be bound by an equitable obligation unless she first has the opportunity to reason morally as to the right course of action, the language of conscience can be said to encourage active moral agency by inviting us as citizens to work out what we ought (morally) to do in any given situation. ${ }^{197}$ In these ways, the language of conscience contributes to the conditions under which private law is regarded as having moral legitimacy, ${ }^{198}$ which in turn makes it easier for people to accept its authority. ${ }^{199}$

That leaves us with the difficulty that the invocation of the language of conscience in relation to both equitable obligations and primary liabilities can generate confusion and uncertainty. Its presence in both contexts tends to obscure the difference between moral duties which are directly enforced as equitable obligations, and moral duties, which either have no legal effect at all or, at most, disable the defendant from exercising her legal rights. However, this confusion can be addressed in one of two ways. The language of conscience can be restricted to cases where the courts are underwriting moral duties as legal or equitable obligations, so that effectively, it becomes a term of art. Alternatively, the courts can be more explicit and precise about the contexts in which the language of conscience is used, and its explanatory limits as a concept, in the manner argued for in this article. The alternative is to abandon the language of conscience completely, but then something valuable would be lost.

\footnotetext{
193 J. Gardner, 'Rationality and the Rule of Law in Offences Against the Person' (1994) 53 CLJ 502.

194 Jaffey (n xx) 41.

195 Hart ( $n x x$ ) 203; Green ( $\mathrm{xx}$ ) 519; but cf Gardner, 'Obligations and Outcomes' ( $\mathrm{xx}$ ) 15, 16; and S. Smith ( $\mathrm{n}$ xx) 163.

196 J. Gardner, 'Obligations and Outcomes in the Law of Torts' in P. Cane \& J. Gardner (eds) Relating to Responsibility: Essays for Tony Honoré (Hart 2001) 15; C. Webb, Reason and Restitution (OUP 2016) 23.

197 S. Shiffrin, 'Inducing Moral Deliberation: On the Occasional Virtues of Fog' (2010) 123 Harv L Rev 1214, 1223; Samet (n 14) 34.

${ }^{198}$ Samet (n 14); I. Samet, Equity: Conscience Goes to Market (Singapore Symposium in Legal Theory 2015) (https://www.youtube.com/watch?v=AgA8z68QhtY 2015).

${ }^{199}$ R. Duff, 'Legal Obligation and the Moral Nature of Law' [1980] Jurisprudence Review 61, 85.
} 